\title{
Adsorption of Cadmium(II) Using Ca/AI Layered Double Hydroxides Intercalated with Keggin Ion
}

\author{
Tarmizi Taher ${ }^{1}$, Yunita Irianty ${ }^{2}$, Risfidian Mohadi ${ }^{2}$, Muhammad Said ${ }^{2}$, \\ Roy Andreas ${ }^{3}$, and Aldes Lesbani ${ }^{1,2, *}$ \\ ${ }^{1}$ Environmental Science Study, Graduate Program, Universitas Sriwijaya, \\ Jl. Padang Selasa, Bukit Besar, Palembang 30139, Indonesia \\ ${ }^{2}$ Department of Chemistry, Faculty of Mathematics and Natural Sciences, Universitas Sriwijaya, \\ Jl. Palembang Prabumulih Km. 32, Ogan Ilir 30662, Indonesia \\ ${ }^{3}$ Department of Chemistry, Faculty of Mathematics and Natural Sciences, Universitas Jenderal Soedirman, \\ Jl. Dr. Soeparno, Karangwangkal, Purwokerto Utara, Banyumas, 53123, Indonesia
}

\section{* Corresponding author:}

email:aldeslesbani@pps.unsri.ac.id

Received: June 23, 2018

Accepted: September 5, 2018

DOI: $10.22146 / \mathrm{ijc} .36447$

\begin{abstract}
Ca/Al layered double hydroxides ( $\mathrm{Ca} / \mathrm{Al} \mathrm{LDH})$ was synthesized using coprecipitation method following calcination at $800{ }^{\circ} \mathrm{C}$ and was intercalated with Keggin ion $\left[\alpha-\mathrm{SiW}_{12} \mathrm{O}_{40}\right]^{4-}$ to form intercalated $\mathrm{Ca} / \mathrm{Al} \mathrm{LDH}$. Materials were characterized using XRD and FTIR spectrophotometer. Furthermore, materials were used as an adsorbent of cadmium(II) from solution. The results showed that layer material was formed completely after calcination which was indicated at diffraction $20^{\circ}$ due to loss of water in the interlayer space. $\mathrm{Ca} / \mathrm{Al} \mathrm{LDH}$ after calcination was intercalated with $\left[\alpha-\mathrm{Si}_{12} \mathrm{O}_{40}\right]^{4-}$ ion and interlayer distance was increased from 4.25 to $4.41 \AA$ showed that intercalation process was successfully conducted. Adsorption of cadmium(II) using Ca/Al LDH was conducted at $\mathrm{pH} 9$ and intercalated $\mathrm{Ca} / \mathrm{Al} \mathrm{LDH}$ at $\mathrm{pH} 8$ showed that intercalated material has slightly faster than $\mathrm{Ca} / \mathrm{Al} \mathrm{LDH}$ without intercalation probably due to slightly increasing interlayer distance of $\mathrm{Ca} / \mathrm{Al} \mathrm{LDH}$ after intercalation. The adsorption capacity of intercalated $\mathrm{Ca} / \mathrm{Al} \mathrm{LDH}$ was higher than $\mathrm{Ca} / \mathrm{Al} \mathrm{LDH}$ without intercalation at the temperature range of $30-50{ }^{\circ} \mathrm{C}$.
\end{abstract}

Keywords: Ca/Al LDH; intercalation; $\left[\alpha-\mathrm{SiW}_{12} \mathrm{O}_{40}\right]^{4-}$; adsorption; cadmium(II)

\section{- INTRODUCTION}

Basically, the presence of various heavy metal in the environment is essential for supporting the life of any living creatures. However, the entering of many heavy metals into the open environment due to the effluent discharge from various anthropogenic activities leads to numerous environmental problems [1]. Cadmium is one of the most toxic heavy metals caused by its high tendency for bioaccumulation and high mobility in the environment [2]. Moreover, cadmium is classified as the top ten of the most dangerous chemicals for human health and it cannot naturally be removed or reduces. According to the World Health Organization (WHO), the limit of permissible cadmium concentration in the groundwater is less than $3 \mu \mathrm{g} / \mathrm{L}$. Even though, cadmium is still widely used in many industrial process such as batteries, color pigment, and electroplating [2]. Hence the removal of cadmium from aqueous solution is a mandatory in order to maintain the environmental live cycles and to support the green environment process.

Until the recent decade, numerous attempts in the heavy metal reduction and removal from the environment have been carried out all over the world. Various physical and chemical methods have been developed like oxidation of metal, filtration, coagulation, membrane separation, and also adsorption [3-4]. Among these methods, adsorption is considered as the most suitable to remove contamination of heavy metals from wastewater [5]. The successful adsorption process 
depends on the properties and capability of the used adsorbent. Various adsorbents have been used for adsorption of heavy metals such as zeolites, clay materials, bentonite, kaolin, metal oxides, layered double hydroxides, and also organic adsorbent [6-9].

Layered double hydroxides (LDH) is inorganic layer materials consisting of divalent $\left(\mathrm{M}^{2+}\right)$ and trivalent $\left(\mathrm{M}^{3+}\right)$ metal cations with anion in interlayer space. The general formula of $\mathrm{LDH}$ is given as $\left[\mathrm{M}^{2+}{ }_{1-\mathrm{x}} \mathrm{M}^{3+}{ }_{\mathrm{x}}(\mathrm{OH})_{2}\right]^{\mathrm{x}+}$ $\left.\left(\mathrm{A}^{\mathrm{n}-}\right)_{\mathrm{x} / \mathrm{n}}\right] \cdot \mathrm{nH}_{2} \mathrm{O}$, where $\mathrm{M}$ is divalent and trivalent metal ions and $\mathrm{A}^{\mathrm{n}-}$ is interlayer anions with valence $\mathrm{n}$ [10-11]. Common divalent cations for the synthesis of LDH are group 2, $\mathrm{Cu}^{2+}, \mathrm{Zn}^{2+}$, and divalent transition metals. Trivalent cations are $\mathrm{Al}^{3+}, \mathrm{Mn}^{3+}, \mathrm{Fe}^{3+}, \mathrm{Co}^{3+}$, and $\mathrm{Cr}^{3+}$ and also other trivalent transition metals. Anion in the interlayer space is commonly from a synthetic solution such as nitrate, chloride, and carbonate [12]. The unique properties of $\mathrm{LDH}$ are flexibility, where anion in the interlayer space can be exchangeable depending on the application of LDH. Exchangeable anion in the interlayer distance is like a guest of materials and easily to exchange in order to obtain unique properties of LDH. LDH has been applied for adsorbent of heavy metal ions such as $\mathrm{Pb}^{2+}$ [13], $\mathrm{Cu}^{2+}[14], \mathrm{In}^{3+}$ [15], and $\mathrm{Cd}^{2+}$ [10] from aqueous solution.

Polyoxometalates are early transition metal clusters consists of addenda ( $\mathrm{W}, \mathrm{Mo}, \mathrm{V}$, etc) and heteroatoms (P, $\mathrm{Si}, \mathrm{B}, \mathrm{Co}$, etc) [16-17]. Polyoxometalates have various size, shape, and also have a unique solubility, acid-base, and redox properties. The solubility of polyoxometalates is depending on counterions to form large anion clusters [18-19]. Recently, polyoxometalate anion has been widely used as large anion to be inserted into the interlayer space of LDH to form materials with unique properties for various applications such as adsorption and catalysis. Polyoxometalates with Keggin, Dawson, and Anderson types are frequently used as anion for intercalating the interlayer $\mathrm{LDH}$ to increase its interlayer distance.

In order to enhance the adsorption capacity of $\mathrm{Ca} / \mathrm{Al}$ $\mathrm{LDH}$, here we have applied the Keggin-type of $[\alpha-$ $\left.\mathrm{SiW}_{12} \mathrm{O}_{40}\right]^{4-}$ polyoxometalate to be intercalated into $\mathrm{Ca} / \mathrm{Al}$ $\mathrm{LDH}$. As reported by $\mathrm{Ma}$ et al., intercalation of $\left[\mathrm{PW}_{12} \mathrm{O}_{40}\right]^{3-}$ polyoxometalate onto $\mathrm{Mg}-\mathrm{Al} \mathrm{LDH}$ has successfully increased its surface area [20]. Herein, we report the synthesis of $\mathrm{Ca} / \mathrm{Al} \mathrm{LDH}$ intercalated by [ $\alpha$ $\left.\mathrm{SiW}_{12} \mathrm{O}_{40}\right]^{4-}$ polyoxometalate which has a similar structure with $\left[\mathrm{PW}_{12} \mathrm{O}_{40}\right]^{3-}$ namely Keggin ion using coprecipitation followed by ion exchange method. The product was then utilized as an adsorbent in the removal of toxic heavy metal i.e., $\mathrm{Cd}^{2+}$, from aqueous solution. For the comparison, $\mathrm{Ca} / \mathrm{Al} \mathrm{LDH}$ without intercalated with polyoxometalate was also prepared as tested for $\mathrm{Cd}^{2+}$ adsorption.

\section{- EXPERIMENTAL SECTION}

\section{Materials}

Chemicals such as sodium tungstate $\left(\mathrm{Na}_{2} \mathrm{WO}_{4} \times 2 \mathrm{H}_{2} \mathrm{O}\right)$, hydrochloric acid $(\mathrm{HCl})$, sodium metasilicate $\left(\mathrm{Na}_{2} \mathrm{O}_{3} \mathrm{Si}\right)$, potassium chloride $(\mathrm{KCl})$, sodium carbonate $\left(\mathrm{Na}_{2} \mathrm{CO}_{3}\right)$, sodium hydroxide $(\mathrm{NaOH})$, potassium hydroxide $(\mathrm{KOH})$, sodium chloride $(\mathrm{NaCl})$, cadmium(II) nitrate $\left(\mathrm{Cd}\left(\mathrm{NO}_{3}\right)_{2}\right)$, calcium nitrate $\left(\mathrm{Ca}\left(\mathrm{NO}_{3}\right)_{2} \times 4 \mathrm{H}_{2} \mathrm{O}\right)$, and aluminum(III) nitrate $\left(\mathrm{Al}\left(\mathrm{NO}_{3}\right)_{3} \times 9 \mathrm{H}_{2} \mathrm{O}\right)$ were obtained from Merck and Sigma Aldrich and directly used without further purification with grade $>99 \%$. Water was purified using cycling ion exchange process by Purite ${ }^{\circledR}$ water system technology at $\mathrm{pH} 7$ at an integrated research laboratory, graduate school, Universitas Sriwijaya.

\section{Instrumentation}

The analysis was conducted using a Shimadzu FTIR Prestige-21 spectrophotometer. The sample was mixed with $\mathrm{KBr}$ to form $\mathrm{KBr}$ pellet. The measurement was performed at wavenumber $400-4000 \mathrm{~cm}^{-1}$. Analysis of XRD was conducted using X-Ray powder diffraction Rigaku Miniflex-600. The sample was scanned at speed scan $0.1^{\circ} \mathrm{min}^{-1}$. Adsorption of cadmium(II) was determined using a UV spectrophotometer EMC-61PC double beam spectrophotometer by complexation using 1,10-phenanthroline.

\section{Procedure}

\section{Synthesis of Ca/AI LDH}

Synthesis $\mathrm{Ca} / \mathrm{Al}$ layered double hydroxides was conducted according to Granados-Reyes et al. (2017) by the co-precipitation method with slight modification 
[21]. Calcium nitrate and aluminum nitrate with molar ratio 2:1 $\left(\mathrm{Ca}^{2+} / \mathrm{Al}^{3+}\right)$ were prepared by adding sodium hydroxide $2 \mathrm{M}$. The mixtures were stirred at $60^{\circ} \mathrm{C}$ and $\mathrm{pH}$ was adjusted to 11 by adding sodium hydroxide. The mixtures were stirring until $\mathrm{pH}$ constant. After stable $\mathrm{pH}$, the mixtures were heated using autoclave at $120^{\circ} \mathrm{C}$ for $2 \mathrm{~h}$. The mixtures were filtered at room temperature and washed with water and dried at $80^{\circ} \mathrm{C}$ overnight to form white solid $\mathrm{Ca} / \mathrm{Al}$ layered double hydroxides. Calcination of $\mathrm{Ca} / \mathrm{Al}$ layered double hydroxides was performed at $800{ }^{\circ} \mathrm{C}$ for $3 \mathrm{~h}$ with a heating rate of $300{ }^{\circ} \mathrm{C} / \mathrm{h}$. Characterization was performed using XRD and FTIR analyses.

\section{Synthesis of Keggin ion [ $\left.\alpha-\mathrm{SiW}_{12} \mathrm{O}_{40}\right]^{4-}$ [22]}

Keggin ion of $\left[\alpha-\mathrm{SiW}_{12} \mathrm{O}_{40}\right]^{4-}$ was obtained as potassium salt $\mathrm{K}_{4}\left[\alpha-\mathrm{SiW}_{12} \mathrm{O}_{40}\right]$ as follows using sodium salts of starting materials. Sodium metasilicate (11.0 g) was dissolved into $100 \mathrm{~mL}$ of water (solution A). Sodium tungstate $(182.0 \mathrm{~g})$ was dissolved into $300 \mathrm{~mL}$ of boiling water (solution B). A solution of $4 \mathrm{M} \mathrm{HCl}(165 \mathrm{~mL})$ was added drop by drop to solution A over 5 min with vigorous stirring in order to dissolve the local precipitate of tungstic acid. Then solution A was added quickly to solution B followed by adding $50 \mathrm{~mL}$ of $4 \mathrm{M} \mathrm{HCl}$. The $\mathrm{pH}$ was adjusted to 6 . The solution was kept at $373 \mathrm{~K}$ for $1 \mathrm{~h}$. A solution of $1 \mathrm{M}$ sodium tungstate $(50 \mathrm{~mL})$ and immediately thereafter, $80 \mathrm{~mL}$ of $4 \mathrm{M} \mathrm{HCl}$ were added. The solution was filtered after cooling to room temperature. The potassium salt of $\mathrm{K}_{4}\left[\alpha-\mathrm{SiW}_{12} \mathrm{O}_{40}\right]$ was obtained by adjusting $\mathrm{pH}$ to around 2 with aqueous $1 \mathrm{M}$ $\mathrm{KOH}$ and then solid $\mathrm{KCl}(50 \mathrm{~g})$ was added. A white precipitate of $\mathrm{K}_{4}\left[\alpha-\mathrm{SiW}_{12} \mathrm{O}_{40}\right]$ was obtained. $\mathrm{K}_{4}\left[\alpha-\mathrm{SiW}_{12} \mathrm{O}_{40}\right]$ was characterized using FT-IR spectrophotometer.

\section{Intercalation Ca/AI LDH with Keggin ion of [ $\alpha$ - $\left.\mathrm{SiW}_{12} \mathrm{O}_{40}\right]^{4-}$}

Intercalation of $\mathrm{Ca} / \mathrm{Al}$ layered double hydroxides with $\left[\alpha-\mathrm{SiW}_{12} \mathrm{O}_{40}\right]^{4-}$ was carried out according to work done by $\mathrm{Ma}$ et al. [20] with slight modification using an ion exchange method as follows. Polyoxometalate of $\mathrm{K}_{4}\left[\alpha-\mathrm{SiW}_{12} \mathrm{O}_{40}\right] \cdot \mathrm{nH}_{2} \mathrm{O}(1.0 \mathrm{~g})$ was dissolved with $50 \mathrm{~mL}$ of water. $\mathrm{Ca} / \mathrm{Al}$ layered double hydroxides $(2 \mathrm{~g})$ was mixed with $25 \mathrm{~mL}$ of $1 \mathrm{M}$ sodium hydroxide. Into this mixture was added a solution of polyoxometalate with gentle stirring under nitrogen condition. The reaction was performed at $24 \mathrm{~h}$ to form a white suspension. The white suspension was filtered by dry vacuum and wash with water several times. The solid material was kept at 110 ${ }^{\circ} \mathrm{C}$ for 2 days. The product of intercalated $\mathrm{Ca} / \mathrm{Al}$ with $[\alpha-$ $\left.\mathrm{SiW}_{12} \mathrm{O}_{40}\right]^{4-}$ was analyzed using XRD powder analysis and identification using FTIR spectroscopy.

\section{pH PZC analysis}

The $\mathrm{pH}$ Point Zero Charges ( $\mathrm{pH}$ PZC) were measured using a solution of sodium chloride $0.1 \mathrm{M}$ as follows. Sodium chloride $0.1 \mathrm{M}$ was adjusted from $\mathrm{pH} 1$ to 10 by addition of sodium hydroxide or hydrochloric acid $0.1 \mathrm{M}$. In the series of sodium chloride solution with various $\mathrm{pH}$, about $1.0 \mathrm{~g}$ of $\mathrm{Ca} / \mathrm{Al}$ layered double hydroxides was added. The mixtures were kept for $24 \mathrm{~h}$ in constant stirring. Mixtures were filtered and $\mathrm{pH}$ of the filtrate was determined by $\mathrm{pH}$ meter. $\mathrm{pH}$ PZC graph was obtained by comparison initial and final $\mathrm{pH}$ solution.

\section{Adsorption studies}

Adsorption of cadmium(II) using $\mathrm{Ca} / \mathrm{Al} \mathrm{LDH}$ and intercalated $\mathrm{Ca} / \mathrm{Al}$ was performed by the studied effect of $\mathrm{pH}$, adsorption time, the initial concentration of cadmium(II), and temperature. The acidity of adsorption was investigated by varying at $\mathrm{pH} 1,2,3,4$, $5,6,7$, and 8 . Adsorption time was studied by varying the time at $10,20,30,40,50,60$, and 90 min using $0.1 \mathrm{~g}$ of adsorbent. Effect initial concentration of cadmium(II) and the temperature was studied using concentration of $10,20,30,40,50$, and $60 \mathrm{mg} / \mathrm{L}$ at 30,40 , and $50^{\circ} \mathrm{C}$. The filtrate of the solution after adsorption was complexed with 1,10-phenanthroline and was analyzed using UV at $\lambda 326 \mathrm{~nm}$. The adsorption performance in term of adsorption capacity $\left(\mathrm{q}_{\mathrm{e}}\right)$ and adsorption efficiency can be calculated by the following equation.

$$
\begin{aligned}
& \mathrm{q}_{\mathrm{e}}=\frac{\left(\mathrm{C}_{\mathrm{e}}-\mathrm{C}_{\mathrm{t}}\right)}{\mathrm{m}} \cdot \mathrm{V} \\
& \% \text { Removal }=\frac{\left(\mathrm{C}_{\mathrm{o}}-\mathrm{C}_{\mathrm{t}}\right)}{\mathrm{C}_{\mathrm{o}}} \times 100
\end{aligned}
$$




\section{- RESULTS AND DISCUSSION}

Characterization of $\mathrm{Ca} / \mathrm{Al} \mathrm{LDH}$ was performed using XRD powder analysis as shown in Fig. 1(a). Specific diffraction of $\mathrm{Ca} / \mathrm{Al} \mathrm{LDH}$ was reported by GranadosReyes et al. [21] in which diffraction appeared at 10-50. Synthesized $\mathrm{Ca} / \mathrm{Al} \mathrm{LDH}$ as shown in Fig. 1(a) has small diffraction at $10^{\circ}$ and high diffraction at $20-30^{\circ}$ indicated the crystalline phase of $\mathrm{Ca} / \mathrm{Al} \mathrm{LDH}$ due to nitrate and carbonate. The presence of nitrate and carbonate can be explained by synthetic materials because of atmospheric air conditions. This anion was located between interlayer of $\mathrm{Ca} / \mathrm{Al} \mathrm{LDH}$. Calcination was performed at $800^{\circ} \mathrm{C}$ in the air at $3 \mathrm{~h}$ and diffraction was shown in Fig. 1 . The intensity of calcite, which was recorded at $2 \theta$ around $30^{\circ}$ [23], increased by increasing temperature. Other phases were detected as Katoite at $17.3^{\circ}$ [211], $20.11^{\circ}$ [220], 28.5 [321], $31.9^{\circ}$ [400], $36.58^{\circ}[420], 39.3^{\circ}$ [431], 44.6 ${ }^{\circ}$ [521], $52.8^{\circ}$ [611], 55.0 $[640], 57.74^{\circ}$ [642], mayenite at $53^{\circ}$ [640], and $56^{\circ}$ [642] (JCPDS24-0217) [24]. The concentration of calcite was decreased to $800{ }^{\circ} \mathrm{C}$ because this compound decomposes at a lower temperature than mayenite and calcium oxide. Layer materials of $\mathrm{Ca} / \mathrm{Al}$ was identified as mayenite $\mathrm{Ca}_{12} \mathrm{Al}_{14} \mathrm{O}_{33}$. The interlayer distance of $\mathrm{Ca} / \mathrm{Al}$ LDH was identified at diffraction $20^{\circ}$ [220] resulted in gallery $4.25 \AA$.

Polyoxometalate $\mathrm{K}_{4}\left[\alpha-\mathrm{SiW}_{12} \mathrm{O}_{40}\right] \cdot \mathrm{nH}_{2} \mathrm{O}$ is a crystalline material. As shown in Fig. 1, the X-ray diffraction pattern of the synthesized Keggin polyoxometalate exhibited several sharp diffraction peaks at $2 \theta=7-10^{\circ}, 16-22^{\circ}, 25-$ $30^{\circ}$, and $32-38^{\circ}$. This finding revealed that the synthesized material is appropriate with the Keggin structure since these diffraction peaks are the typical diffraction pattern of Keggin polyoxometalate [25]. Intercalation of $\mathrm{Ca} / \mathrm{Al} \mathrm{LDH}$ with $\mathrm{K}_{4}\left[\alpha-\mathrm{SiW}_{12} \mathrm{O}_{40}\right] \cdot \mathrm{nH}_{2} \mathrm{O}$ resulted in diffraction as indicated in Fig. 1. Keggin ion of $\left[\alpha-\mathrm{SiW}_{12} \mathrm{O}_{40}\right]^{4-}$ was identified at diffraction $9^{\circ}$ with small intensities (24.71 cts). Layered material of $\mathrm{Ca} / \mathrm{Al}$ was detected at diffraction $20^{\circ}$ with high intensities. Several diffractions were detected at $30,32,35,36$, and $40^{\circ}$ due to insertion of Keggin ion to replace nitrate and water molecules.

After intercalation process, the Miller indices [220] peak was shifted to the lower $2 \theta$ value, particularly from $20.88^{\circ}$ to $20.11^{\circ}$ producing the increase of the $d(220)$ basal spacing from $4.25 \AA$ to $4.41 \AA$. Although there was a slight increase of the interlayer distance, this finding is an indication that the intercalation process was successfully conducted. The diameter of Keggin ion is $9.8 \AA[20,26]$, thus intercalation process will increase gallery around $\pm 0.16 \AA$. Intercalation process in this experiment showed that the position of Keggin ion probably in a diagonal position, not in a vertical position as illustrated in Fig. 2.

Identification using FTIR spectroscopy was shown in Fig. 3. Unique vibrations of $\mathrm{Ca} / \mathrm{Al} \mathrm{LDH}$ as identified in Fig. 3(a) were identified at wavenumber 660 and $790 \mathrm{~cm}^{-1}$,
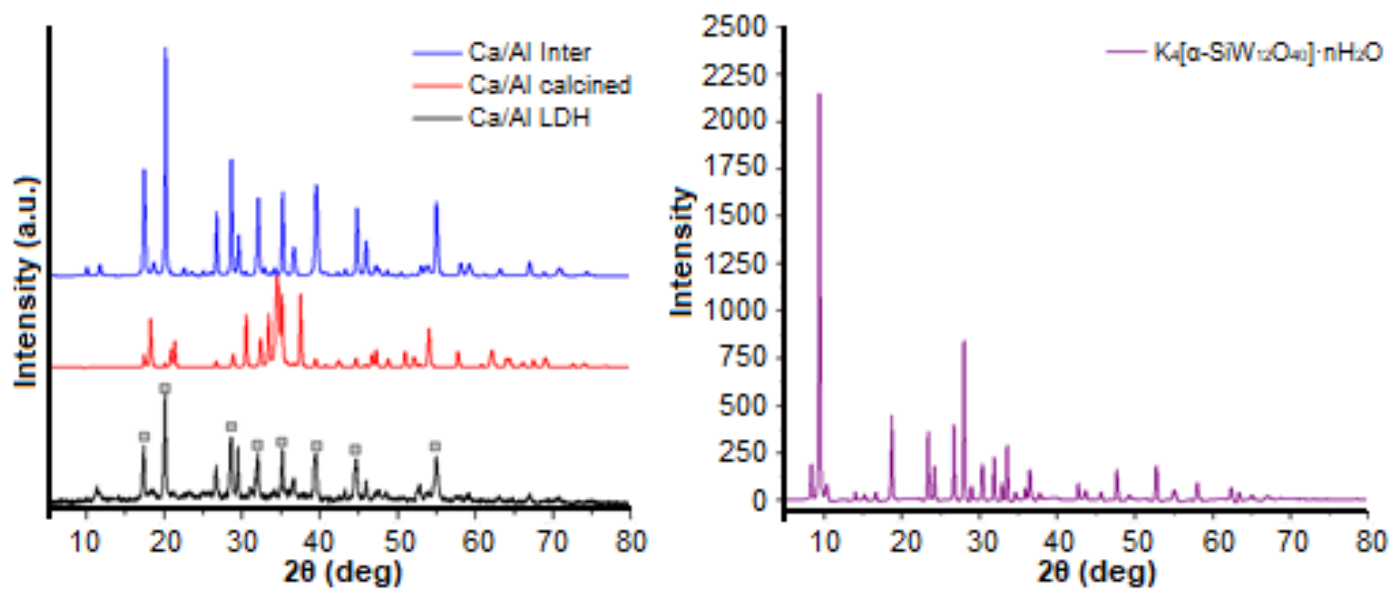

Fig 1. $\mathrm{XRD}$ powder patterns of $\mathrm{Ca} / \mathrm{Al} \mathrm{LDH}$, calcination of $\mathrm{Ca} / \mathrm{Al} \mathrm{LDH}$ at $800{ }^{\circ} \mathrm{C}$, polyoxometalate $\mathrm{K}_{4}[\alpha-$ $\left.\mathrm{SiW}_{12} \mathrm{O}_{40}\right] \cdot \mathrm{nH}_{2} \mathrm{O}$ and intercalated $\mathrm{Ca} / \mathrm{Al} \mathrm{LDH}$ with $\mathrm{K}_{4}\left[\alpha-\mathrm{SiW}_{12} \mathrm{O}_{40}\right] \cdot \mathrm{nH}_{2} \mathrm{O}$ 


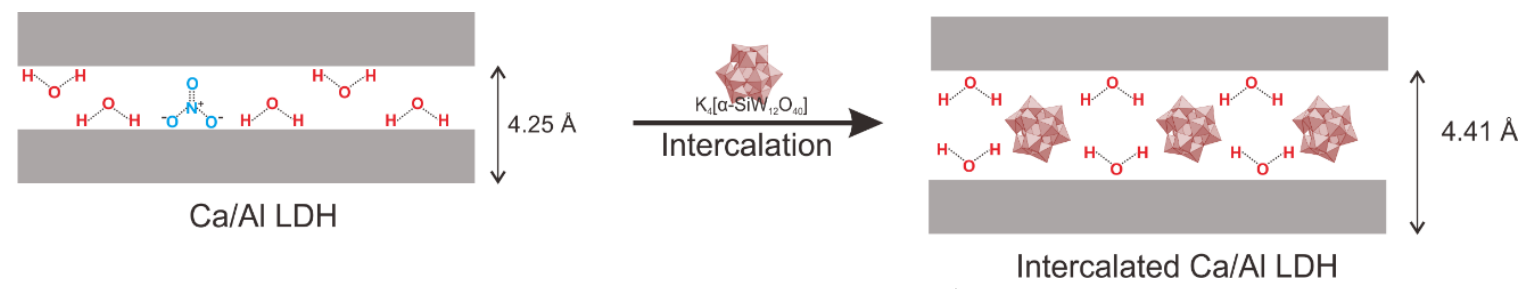

Fig 2. The plausible position of $\left[\alpha-\mathrm{SiW}_{12} \mathrm{O}_{40}\right]^{4-}$ toward $\mathrm{Ca} / \mathrm{Al} \mathrm{LDH}$

which were assigned as $\mathrm{Ca}-\mathrm{O}$ and $\mathrm{Al}-\mathrm{O}$ vibrations, respectively. Generally, calcination by increasing temperature creates sharp vibration at $700-800 \mathrm{~cm}^{-1}$. We observed small vibration after calcination due to water and nitrate ions between interlayer space is still remains probably due to hydrogen bonding. The vibration of $\mathrm{OH}$ at $3300 \mathrm{~cm}^{-1}$ was also to be sharped due to loss of water and $\mathrm{OH}$ vibration is assigned as bonding $\mathrm{OH}$ with metal $\mathrm{M}^{2+} / \mathrm{M}^{3+}$ [27]. On the other hand, the vibration of nitrate at $1380 \mathrm{~cm}^{-1}$ was a boarder and split with increasing calcination temperature due to the stability of nitrate ion toward high temperature (Fig. 3(b)). Polyoxometalate $\mathrm{K}_{4}\left[\alpha-\mathrm{SiW}_{12} \mathrm{O}_{40}\right] \cdot \mathrm{nH}_{2} \mathrm{O}$ as indicated in Fig. 3(c) has the specific vibration of $\mathrm{Si}-\mathrm{O}$ at $926 \mathrm{~cm}^{-1}, \mathrm{~W}=\mathrm{O}$ at $980 \mathrm{~cm}^{-1}$, $\mathrm{W}-\mathrm{Oc}-\mathrm{W}$ at $881 \mathrm{~cm}^{-1}$, and $\mathrm{W}-\mathrm{Oe}-\mathrm{W}$ at $780 \mathrm{~cm}^{-1}$. Intercalation of $\mathrm{Ca} / \mathrm{Al} \mathrm{LDH}$ with Keggin ion of [ $\alpha-$ $\left.\mathrm{SiW}_{12} \mathrm{O}_{40}\right]^{4-}$ has a broad vibration at $1472 \mathrm{~cm}^{-1}$. These vibrations were shifted to higher wavenumber (1400 to $1472 \mathrm{~cm}^{-1}$ ) due to Keggin ion replace nitrate ion in $\mathrm{Ca} / \mathrm{Al}$ $\mathrm{LDH}$ [28]. Thus, intercalation of $\mathrm{Ca} / \mathrm{Al} \mathrm{LDH}$ using intercalant $\left[a-\mathrm{SiW}_{12} \mathrm{O}_{40}\right]^{4-}$ was successfully conducted. For further utilization, the material was used as an adsorbent of cadmium (II) from aqueous solution.

Stability of $\mathrm{Ca} / \mathrm{Al} \mathrm{LDH}$ and intercalated $\mathrm{Ca} / \mathrm{Al} \mathrm{LDH}$ was firstly identified before adsorption process using $\mathrm{pH}$ PZC. The results of $\mathrm{pH} \mathrm{PZC}$ for $\mathrm{Ca} / \mathrm{Al} \mathrm{LDH}$ and intercalated $\mathrm{Ca} / \mathrm{Al} \mathrm{LDH}$ are given in Fig. 4.

The graph of $\mathrm{pH}$ PZC in Fig. 4 showed that the intersection point was appeared at $\mathrm{pH} 9$ for $\mathrm{Ca} / \mathrm{Al} \mathrm{LDH}$ and at $\mathrm{pH} 8$ for intercalated $\mathrm{Ca} / \mathrm{Al} \mathrm{LDH}$. Both $\mathrm{Ca} / \mathrm{Al} \mathrm{LDH}$ and intercalated $\mathrm{Ca} / \mathrm{Al} \mathrm{LDH}$ are base materials. $\mathrm{pH}$ PZC indicated zero charges of material. There are no both positive and negative charges at that points [29]. Based on adsorption data, adsorption of cadmium(II) was found optimum at $\mathrm{pH} 4$ for $\mathrm{Ca} / \mathrm{Al} \mathrm{LDH}$ and at $\mathrm{pH} 3$ for intercalated $\mathrm{Ca} / \mathrm{Al} \mathrm{LDH}$. These results were different from

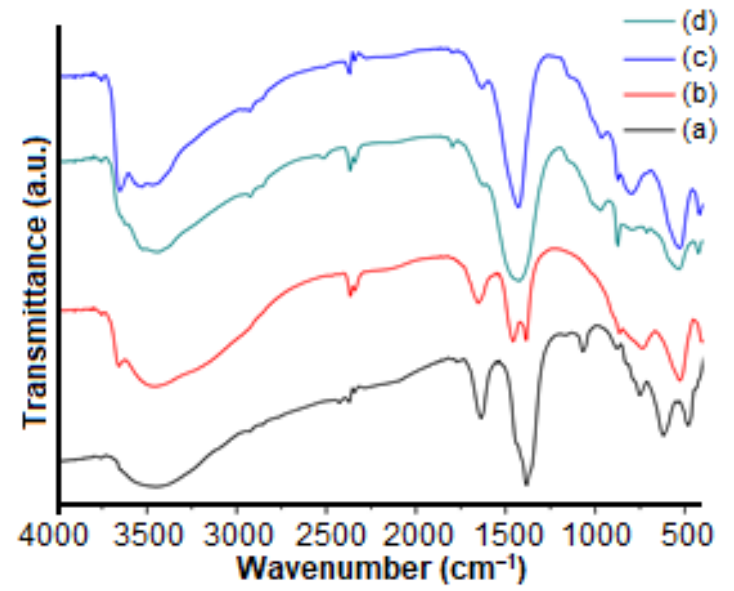

Fig 3. FTIR spectrum of (a) $\mathrm{Ca} / \mathrm{Al} \mathrm{LDH}$, (b) calcination of $\mathrm{Ca} / \mathrm{Al} \mathrm{LDH}$ at $800{ }^{\circ} \mathrm{C}$, (c) polyoxometalate $\mathrm{K}_{4}[\alpha-$ $\left.\mathrm{SiW}_{12} \mathrm{O}_{40}\right] \cdot \mathrm{nH}_{2} \mathrm{O}$, and (d) intercalated $\mathrm{Ca} / \mathrm{Al} \mathrm{LDH}$ with $\mathrm{K}_{4}\left[\alpha-\mathrm{SiW}_{12} \mathrm{O}_{40}\right] \cdot \mathrm{nH}_{2} \mathrm{O}$

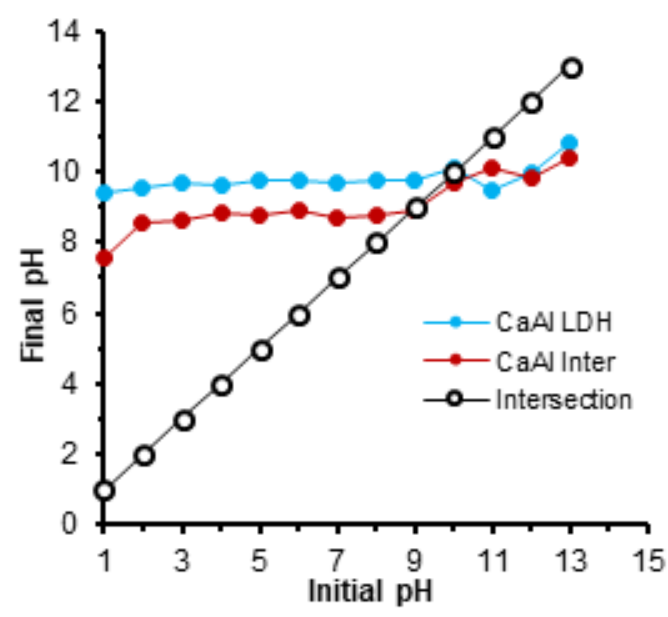

Fig 4. pH PZC graph

$\mathrm{pH}$ PZC analysis due to due to acid properties of Cd(II) on a solution as reported by Jancsó [30]. Cadmium existed in the solution below $\mathrm{pH} 9$ and all cadmium is precipitate as hydroxides at $\mathrm{pH}$ above 9. Thus, the adsorption experiment was conducted at $\mathrm{pH} 4$ for adsorbent $\mathrm{Ca} / \mathrm{Al} \mathrm{LDH}$ and $\mathrm{pH} 3$ for adsorbent intercalated $\mathrm{Ca} / \mathrm{Al} \mathrm{LDH}$. 


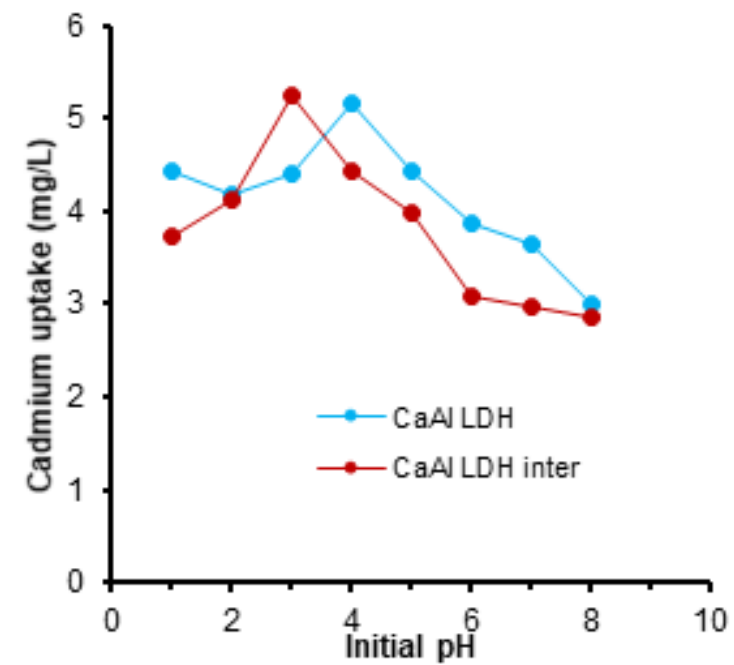

Fig 5. Effect of $\mathrm{pH}$ on adsorption of $\mathrm{Cd}(\mathrm{II})$ onto $\mathrm{Ca} / \mathrm{Al}$ $\mathrm{LDH}$ and intercalated $\mathrm{Ca} / \mathrm{Al} \mathrm{LDH}$

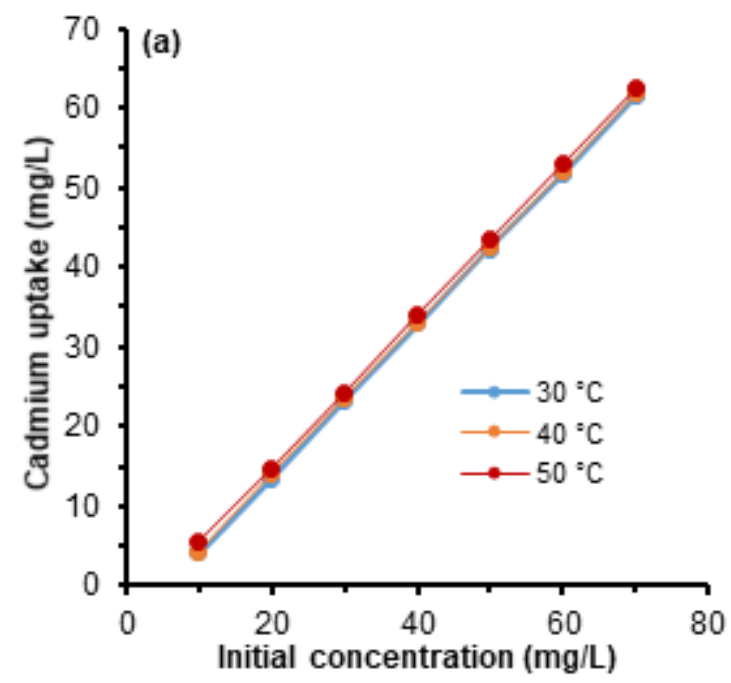

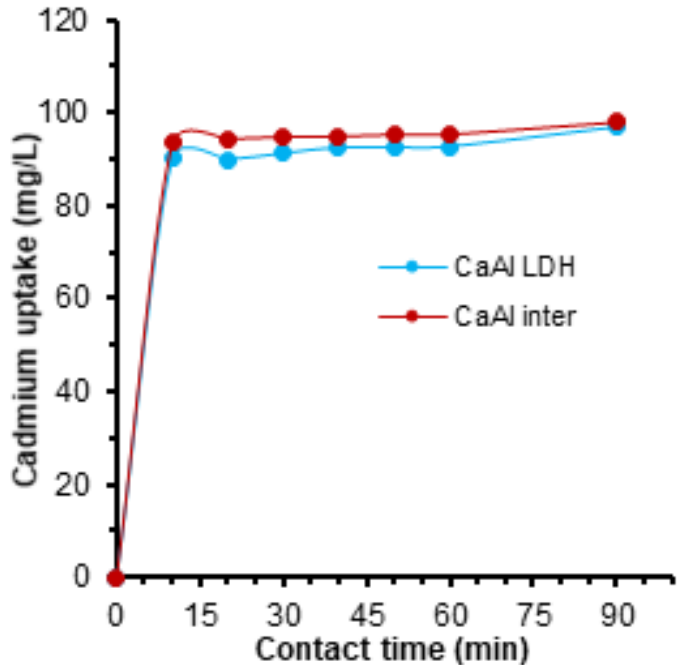

Fig 6. Effect of adsorption time of $\mathrm{Cd}(\mathrm{II})$ on $\mathrm{Ca} / \mathrm{Al} \mathrm{LDH}$ and intercalated $\mathrm{Ca} / \mathrm{Al} \mathrm{LDH}$

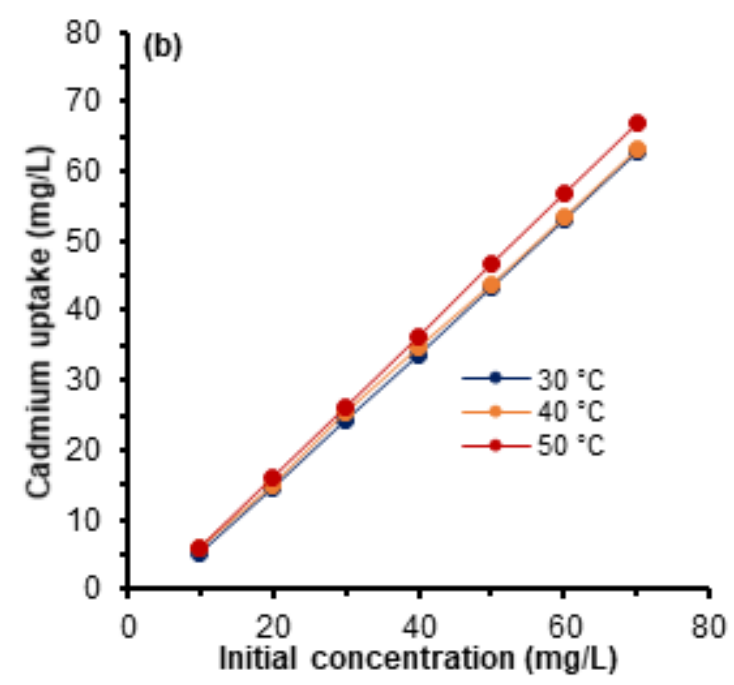

Fig 7. Effect of initial concentration of cadmium (II) and temperature on adsorption using (a) $\mathrm{Ca} / \mathrm{Al} \mathrm{LDH}$ and (b) intercalated $\mathrm{Ca} / \mathrm{Al} \mathrm{LDH}$

Adsorption of cadmium(II) was firstly investigated by studying the effect of adsorption time as shown in Fig. 6. The adsorption profile of cadmium(II) showed that adsorption was faster at an initial time for intercalated $\mathrm{Ca} / \mathrm{Al} \mathrm{LDH}$ than $\mathrm{Ca} / \mathrm{Al} \mathrm{LDH}$. The amount of adsorption was increased sharply by increasing adsorption time. The adsorption rate of data in Fig. 6 was calculated using the Langmuir-Hinshelwood equation [31]. The results showed that intercalated $\mathrm{Ca} / \mathrm{Al} \mathrm{LDH}$ and $\mathrm{Ca} / \mathrm{Al} \mathrm{LDH}$ have adsorption rate of 0.038 and $0.034 \mathrm{~min}^{-1}$, respectively. These data showed that intercalated $\mathrm{Ca} / \mathrm{Al}$
$\mathrm{LDH}$ has reactivity slightly higher than $\mathrm{Ca} / \mathrm{Al} \mathrm{LDH}$ due to slightly increase interlayer distance after the intercalation process.

The further experiment of adsorption was conducted with a different initial concentration of cadmium(II) and temperature as shown in Fig. 7. Only slightly different effect of temperature adsorption in various concentration of cadmium(II). Data in Fig. 7 can be calculated using the Langmuir equation [32], and the results are presented in Table 1.

Data in Table 1 showed that increasing temperature 
Table 1. Adsorption capacity of $\mathrm{Ca} / \mathrm{Al} \mathrm{LDH}$ and intercalated $\mathrm{Ca} / \mathrm{Al} \mathrm{LDH}$

\begin{tabular}{cccc}
\hline $\begin{array}{c}\text { Layered Double } \\
\text { Hydroxides }\end{array}$ & $\begin{array}{c}\text { Temperature } \\
\left({ }^{\circ} \mathrm{C}\right)\end{array}$ & $\begin{array}{c}\text { Adsorption } \\
\text { Capacity }\left(\mathrm{mg} / \mathrm{g}^{-1}\right)\end{array}$ & R-Value \\
\hline $\mathrm{Ca} / \mathrm{Al}$ & 30 & 0.260 & 0.9300 \\
& 40 & 0.945 & 0.9352 \\
& 50 & 1.125 & 0.9902 \\
\hline Intercalated & 30 & 0.479 & 0.9406 \\
$\mathrm{Ca} / \mathrm{Al}$ & 40 & 1.240 & 0.9198 \\
& 50 & 12.578 & 0.9272 \\
\hline
\end{tabular}

would largely increase the adsorption capacity of LDH. The data also indicates intercalated $\mathrm{Ca} / \mathrm{Al} \mathrm{LDH}$ has higher adsorption capacity than $\mathrm{Ca} / \mathrm{Al}$ without intercalation Keggin ion. Adsorption of cadmium(II) is largely increased at $50{ }^{\circ} \mathrm{C}$ on intercalated $\mathrm{Ca} / \mathrm{Al} \mathrm{LDH}$ probably because adsorption occurred not only on the surface of intercalated $\mathrm{Ca} / \mathrm{Al} \mathrm{LDH}$ but also onto interlayer distance. Thus, intercalation of $\mathrm{Ca} / \mathrm{Al} \mathrm{LDH}$ will give a significant effect for the adsorption of cadmium(II) in aqueous solution.

\section{- CONCLUSION}

In this work, $\mathrm{Ca} / \mathrm{Al} \mathrm{LDH}$ intercalated with Keggin ion $\left[\alpha-\mathrm{SiW}_{12} \mathrm{O}_{40}\right]^{4-}$ was successfully prepared; it was proofed by increasing the interlayer distance of the $\mathrm{Ca} / \mathrm{Al}$ $\mathrm{LDH}$ structure. Since the increase of the interlayer distance occurred in slight, we assumed that the insertion of the Keggin ion into the interlayer space was in diagonal position. The both $\mathrm{Ca} / \mathrm{Al} \mathrm{LDH}$ and intercalated $\mathrm{Ca} / \mathrm{Al}$ LDH were tested to adsorb cadmium(II) ion from aqueous solution. According to the adsorption kinetic study, the adsorption of cadmium(II) onto intercalated Ca/Al LDH was faster rather than that on without intercalation one. Moreover, the adsorption capacity of intercalated $\mathrm{Ca} / \mathrm{Al}$ $\mathrm{LDH}$ is higher indicating that the intercalated $\mathrm{Ca} / \mathrm{Al} \mathrm{LDH}$ is more effective adsorbent to adsorb cadmium(II) ion from aqueous solution.

\section{- ACKNOWLEDGMENTS}

Authors thank Universitas Sriwijaya for financial support of this research through "Hibah Profesi 20172018" to A.L contract No. 987/UN9.3.1/PP/2017. This research is a part of a collaboration between material research group of Universitas Sriwijaya and Universitas Jenderal Soedirman.

\section{- REFERENCES}

[1] Bhunia, P., Chatterjee, S., Rudra, P., and De, S., 2018, Chelating polyacrylonitrile beads for removal of lead and cadmium from wastewater, Sep. Purif. Technol., 193, 202-213.

[2] Koju, N.K., Song, X., Wang, Q., Hu, Z., and Colombo, C., 2018, Cadmium removal from simulated groundwater using alumina nano particles: Behaviors and mechanisms, Environ. Pollut., 240, 255-266.

[3] Castro, L., Blázquez, M.L., González, F., Muñoz, J.A., and Ballester, A., 2018, Heavy metal adsorption using biogenic iron compounds, Hydrometallurgy, $179,44-51$.

[4] Taher, T., Mohadi, R., and Lesbani, A., 2018, Effect of $\mathrm{Ti}^{4+} /$ clay ratio on the properties of titanium pillared bentonite and its application for $\mathrm{Cr}(\mathrm{VI})$ removal, Rasayan J. Chem., 11, 1244-1254.

[5] Taher, T., Mohadi, R., Rohendi, D., and Lesbani, A., 2017, Kinetic and thermodynamic adsorption studies of congo red on bentonite, AIP Conf. Proc., 1823, 020028.

[6] Fan, C., Li, K., He, Y., Wang, Y., Qian, X., and Jia, J., 2018, Evaluation of magnetic chitosan beads for adsorption of heavy metal ions, Sci. Total Environ., 627, 1396-1403.

[7] Fakhre, N.A., and Ibrahim, B.M., 2018, The use of new chemically modified cellulose for heavy metal ion adsorption, J. Hazard. Mater., 343, 324-331.

[8] Cheng, T.W., Lee, M.L., Ko, M.S., Ueng, T.H., and Yang, S.F., 2012, The heavy metal adsorption characteristics on metakaolin-based geopolymer, Appl. Clay Sci., 56, 90-96.

[9] Qiu, Q., Jiang, X., Lv, G., Chen, Z., Lu, S., Ni, M., Yan, J., and Deng, X., 2018, Adsorption of heavy metal ions using zeolite materials of municipal solid waste incineration fly ash modified by microwaveassisted hydrothermal treatment, Powder Technol., $335,156-163$. 
[10] Mallakpour, S., and Hatami, M., 2017, Biosafe organic diacid intercalated LDH/PVC nano composites versus pure LDH and organic diacid intercalated LDH: Synthesis, characterization and removal behaviour of $\mathrm{Cd}^{2+}$ from aqueous test solution, Appl. Clay Sci., 149, 28-40.

[11] Palapa, N.R., and Said, M., 2016, Keggin type polyoxometalate $\mathrm{H}_{4}\left[\alpha \mathrm{SiW}_{12} \mathrm{O}_{40}\right] \cdot \mathrm{nH}_{2} \mathrm{O}$ as intercalant for hydrotalcite, Sci. Technol. Indonesia, 1, 25-28.

[12] Pourfaraj, R., Fatemi, S.J., Kazemi, S.Y., and Biparva, P., 2017, Synthesis of hexagonal mesoporous MgAl LDH nanoplatelets adsorbent for the effective adsorption of Brilliant Yellow, J. Colloid Interface Sci., 508, 65-74.

[13] Zhou, H., Jiang, Z., and Wei, S., 2018, A new hydrotalcite-like absorbent FeMnMg-LDH and its adsorption capacity for $\mathrm{Pb}^{2+}$ ions in water, Appl. Clay Sci., 153, 29-37.

[14] Chen, H., Lin, J., Zhang, N., Chen, L., Zhong, S., Wang, Y., Zhang, W., and Ling, Q., 2018, Preparation of MgAl-EDTA-LDH based electrospun nanofiber membrane and its adsorption properties of copper(II) from wastewater, J. Hazard. Mater., 345, 1-9.

[15] Barnabas, M.J., Parambadath, S., Mathew, A., Park, S.S., Vinu, A., and Ha, C.S., 2016, Highly efficient and selective adsorption of $\mathrm{In}^{3+}$ on pristine $\mathrm{Zn} / \mathrm{Al}$ layered double hydroxide (Zn/Al-LDH) from aqueous solutions, J. Solid State Chem., 233, 133-142.

[16] Yu, B., Zou, B., and $\mathrm{Hu}$, C.W., 2018, Recent applications of polyoxometalates in $\mathrm{CO}_{2}$ capture and transformation, J. CO2 Util., 26, 314-322.

[17] Jiang, C., Lesbani, A., Kawamoto, R., Uchida, S., and Mizuno, N., 2006, Channel-selective independent sorption and collection of hydrophilic and hydrophobic molecules by $\mathrm{Cs}_{2}\left[\mathrm{Cr}_{3} \mathrm{O}\left(\mathrm{OOCC}_{2} \mathrm{H}_{5}\right)_{6}\right.$ $\left.\left(\mathrm{H}_{2} \mathrm{O}\right)_{3}\right]_{2}\left[\alpha-\mathrm{SiW}_{12} \mathrm{O}_{40}\right]$ ionic crystal, J. Am. Chem. Soc., 128 (44), 14240-14241.

[18] Gao, Y., Gao, R., Zhang, G., Zheng, Y., and Zhao, J., 2018, Oxidative desulfurization of model fuel in the presence of molecular oxygen over polyoxometalate based catalysts supported on carbon nanotubes, Fuel, 224, 261-270.
[19] Uchida, S., Lesbani, A., Ogasawara, Y., and Mizuno, N., 2012, Ionic crystals $\left[\mathrm{M}_{3} \mathrm{O}\left(\mathrm{OOCC}_{6} \mathrm{H}_{5}\right)_{6}\left(\mathrm{H}_{2} \mathrm{O}\right)_{3}\right]$ ${ }_{4}\left[\alpha-\mathrm{SiW}_{12} \mathrm{O}_{40}\right](\mathrm{M}=\mathrm{Cr}, \mathrm{Fe})$ as heterogeneous catalysts for pinacol rearrangement, Inorg. Chem., 51 (2), 775-777.

[20] Ma, J., Yang, M., Chen, Q., Zhang, S., Cheng, H., Wang, S., Liu, L., Zhang, C., Tong, Z., and Chen, Z., 2017, Comparative study of Keggin-type polyoxometalate pillared layered double hydroxides via two synthetic routes: Characterization and catalytic behavior in green epoxidation of cyclohexene, Appl. Clay Sci., 150, 210-216.

[21] Granados-Reyes, J., Salagre, P., and Cesteros, Y., 2017, Effect of the preparation conditions on the catalytic activity of calcined $\mathrm{Ca} / \mathrm{Al}$-layered double hydroxides for the synthesis of glycerol carbonate, Appl. Catal., A, 536, 9-17.

[22] Lesbani, A., and Mohadi, R., 2014, Brönsted acid of Keggin type polyoxometalate catalyzed pinacol rearrangement, Bull. Chem. React. Eng. Catal., 9, 136-141.

[23] Pérez-Barrado, E., Salagre, P., Marsal, L.F., Aguiló, M., Cesteros, Y., Díaz, F., Pallarès, J., Cucinotta, F., Marchese, L., and Pujol, M.C., 2015, Ultrasoundassisted reconstruction and delamination studies on CaAl layered double hydroxides, Appl. Clay Sci., 118, 116-123.

[24] Zhang, H., Chen, H., Azat, S., Mansurov, Z.A., Liu, X., Wang, J., Su, X., and Wu, R., 2018, Super adsorption capability of rhombic dodecahedral CaAl layered double oxides for Congo red removal, $J$. Alloys Compd., 768, 572-581.

[25] Jamshidi, A., Zonoz, F.M., Wei, Y., and Maleki, B., 2018, An organic-inorganic nano-hybrid material containing a mixed-addenda Keggin-type polyoxo metalate, piperazine: Synthesis, characterization, its electrochemical investigation, Inorg. Chim. Acta, 477, 233-241.

[26] Kwon, T., and Pinnavaia, T.J., 1992, Synthesis and properties of anionic clays pillared by $\left[\mathrm{XM}_{12} \mathrm{O}_{40}\right]^{\mathrm{n}-}$ Keggin ions, J. Mol. Catal., 74 (1-3), 23-33.

[27] Hasannia, S., and Yadollahi, B., 2015, Zn-Al LDH 
nanostructures pillared by $\mathrm{Fe}$ substituted Keggin type polyoxometalate: Synthesis, characterization and catalytic effect in green oxidation of alcohols, Polyhedron, 99, 260-265.

[28] Dou, Y., Han, J., Wang, T., Wei, M., Evans, D.G., and Duan, X., 2012, Temperature-controlled electrochemical switch based on layered double hydroxide/poly(N-isopropylacrylamide) ultrathin films fabricated via layer-by-layer assembly, Langmuir, 28 (25), 9535-9542.

[29] Fabryanty, R., Valencia, C., Soetaredjo, F.E., Putro, J.N., Santoso, S.P., Kurniawan, A., Ju, Y.H., and Ismadji, S., 2017, Removal of crystal violet dye by adsorption using bentonite - alginate composite, $J$. Environ. Chem. Eng., 5 (6), 5677-5687.

[30] Jancsó, A., Szunyogh, D., Larsen, F.H., Thulstrup,
P.W., Christensen, N.J., Gyurcsik, B., and Hemmingsen, L., 2011, Towards the role of metal ions in the structural variability of proteins: CdII speciation of a metal ion binding loop motif, Metallomics, 3 (12), 1331-1339.

[31] Wan, D., Li, W., Wang, G., Chen, K., Lu, L., and Hu, Q., 2015, Adsorption and heterogeneous degradation of rhodamine $\mathrm{B}$ on the surface of magnetic bentonite material, Appl. Surf. Sci., 349, 988-996.

[32] Putro, J.N., Santoso, S.P., Ismadji, S., and Ju, Y.H., 2017, Investigation of heavy metal adsorption in binary system by nanocrystalline cellulose Bentonite nanocomposite: Improvement on extended Langmuir isotherm model, Microporous Mesoporous Mater., 246, 166-177. 